\title{
JELLY COMBINATION OF SNAKE FRUIT SEED FLOUR AND MORINGA OLEIFERA LEAF FLOUR TO INCREASE DAILY NUTRIENT INTAKE IN FEMALE ADOLESCENTS WITH MODERATE ANEMIA
}

\author{
Poppy Wijayanti'), Yulia Lanti Retno Dewi²), Dono Indarto3) \\ ${ }^{1)}$ Masters Program in Public Health, Universitas Sebelas Maret \\ ${ }^{2)}$ Department of Nutrition, Faculty of Medicine, Universitas Sebelas Maret \\ 3)Biomedical Laboratory, Faculty of Medicine, Universitas Sebelas Maret
}

\begin{abstract}
Background: Moringa oleifera leaf is one of the richest sources of natural iron and calcium and it is considered a multivitamin supplement with also high amounts of amino acids, among other nutrients. Recent studies reported that $M$. oleifera leaves also contain the greatest amount of protein, vitamin $\mathrm{E}$, vitamin $\mathrm{A}$, vitamin $\mathrm{C}$, vitamin $\mathrm{B}$, calcium, iron and potassium. The purpose of this study was to examine jelly combination of snake fruit seed flour and Moringa Oleifera leaf flour to increase daily nutrient intake in female adolescents with moderate anemia.

Subjects and Method: A randomized control trial was conducted at Senior High Schools in Banyuwangi, East Java. A sample of 50 female students with moderate anemia was selected randomly and divided into 2 groups, (1) 25 students received $100 \mathrm{~g}$ jelly combination of snake fruit seed flour and Moringa oleifera leaf flour (intervention group), and (2) 25 students received 100 g plain jelly + iron tablet (control group). Intervention was provided 2 times a week for 4 weeks. The dependent variable was nutrition intake. The independent variable was jelly combination of snake fruit seed flour and Moringa oleifera leaf flour. Daily nutrition intake was measured by 24 hours food recall. The data were measured on day-14 and day-30 and it was analyzed by repeated Anova.

Results: After day-30 of intervention, mean of carbohydrate (Mean= 318.57; $\mathrm{SD}=$ $17.62)$, protein $(\mathrm{Mean}=86.69 ; \mathrm{SD}=8.76)$, fat $(\mathrm{Mean}=90.23 ; \mathrm{SD}=15.56)$, iron $(\mathrm{Mean}=$ 16.60; $\mathrm{SD}=1.49)$, zinc $(\mathrm{Mean}=9.70 ; \mathrm{SD}=0.98)$, and vitamin $\mathrm{C}(\mathrm{Mean}=119.26 ; \mathrm{SD}=$ 37.86) were higher than the initial day, with $\mathrm{p}=0.001$.

Conclusion: Jelly combination of snake fruit seed flour and Moringa oleifera leaf flour can be used to improve daily nutrition intake female adolescents with moderate anemia.
\end{abstract}

Keywords: iron deficiency anemia, Moringa oleifera leaf flour, snake fruit seed flour, female adolescent

\section{Correspondence:}

Poppy Wijayanti. Masters Program in Public Health, Universitas Sebelas Maret. Jl. Ir. Sutami 36A, Surakarta 57126, Central Java. Email: popzala04@gmail.com. 